\title{
Local ecological and taxonomic knowledge of snapper fish (Teleostei: Actinopterygii) held by fishermen in Ilhéus, Bahia, Brazil
}

\author{
Camilla Fahning Ferreira Caló ${ }^{1}$, Alexandre Schiavetti² ${ }^{2}$ nd Mauricio Cetra ${ }^{3}$
}

Local Ecological and Taxonomic Knowledge (LEK) of fish held by fishermen in the municipality of Ilhéus, Bahia, Brazil, known as the snapper ("vermelho") was examined from August 2005 to November 2006. Semi-structured interviews and tests were made with fishermen selected under the criteria of "specialists". The data analysis followed the union model of the different individual competences. Grouping analysis was performed on data referring to the localities of the occurrence of these fish, depth, coloration, and morphological characteristics of the species using the Pearson correlation coefficient (UPGMA). A total of 19 species were named within the snapper group, although three of them could not be scientifically identified. The Lutjanidae family presented the greatest numbers of species $(n=9)$. Other families mentioned were: the Serranidae $(n=3)$, Holocentridae $(\mathrm{n}=2)$, Priacanthidae $(\mathrm{n}=1)$, Mullidae $(\mathrm{n}=1)$. The 1:1 correspondence between fishermen's local names and scientific species observed in this study indicates the richness of local fishermen knowledge. Analysis of the LEK related to the feeding habits of these fish and indicated that most were considered as being carnivorous, which agrees with the specialized literature consulted. In terms of their spatial distribution, two categories were detected: locality of occurrence (rivers/sea, coast, and offshore) and depth (surface, mid-depth, mid-depth/deep, deep). The fish were considered locally to be "winter fish", based on harvested yields. Most of the interviewees knew little about the reproductive aspects of these fish. The main criteria used to identify, name, and classify the species were based on color and morphological aspects. Much of the information gathered in this study agreed with the published literature, which strengthens the importance of including LEK in planning and decisionmaking processes.

Este estudo analisou o Conhecimento Ecológico Local (CEL) e taxonômico dos peixes conhecidos como vermelhos pelos pescadores no município de Ilhéus, Bahia, no período de agosto de 2005 a novembro de 2006. Foram realizadas entrevistas semi-estruturadas e testes projetivos com os pescadores selecionados pelo critério de "especialistas". A análise dos dados seguiu o modelo de união das diversas competências individuais. Foram realizadas análises de agrupamento para os dados referentes ao ambiente de ocorrência, profundidade, coloração e características morfológicas das espécies, utilizando o coeficiente de correlação de Pearson (UPGMA). No total foram citadas 19 espécies compondo o grupo dos vermelhos, sendo que três não foram identificados cientificamente. A família Lutjanidae foi a que apresentou um maior número de espécies $(\mathrm{n}=9)$. Outras famílias encontradas foram a Serranidae ( $n=3)$, Holocentridae $(n=2)$, Priacanthidae ( $n=1)$ e Mullidae $(n=1)$. A correspondência de 1:1 obtida entre as espécies citadas pelos pescadores e a espécie científica encontrada neste estudo indica um refinado detalhamento na identificação e distinção. Analisando o CEL referente à alimentação destes peixes, pode-se constatar que a maioria é carnívora, o que está de acordo com a literatura especializada consultada. Para a distribuição espacial foram detectadas duas categorizações: ambientes de ocorrência (rio/mar, costeiro e alto mar) e profundidade (raso, meia-água, meia-água/fundo, fundo). Os peixes pesquisados foram considerados como peixes de inverno, afirmação baseada na produção pesqueira. A maioria dos entrevistados desconhece os fatores relacionados com os aspectos reprodutivos. Os principais critérios utilizados para identificar, nomear e classificar as espécies estão relacionados com a coloração e aspectos morfológicos. Muitas das informações citadas neste estudo estão de acordo com a literatura especializada consultada, o que fortalece a importância e inclusão do CEL nos planos de manejo e na tomada de decisões.

Key words: Lutjanidade, Ethnozoology, Traditional fishing.

\footnotetext{
${ }^{1}$ Mamirauá Institute for Sustainable Development - Ornamental Fish Project, Tefé 69470-000, AM, Brazil. cfahning@hotmail.com ${ }^{2}$ Department of Agrarian and Environmental Sciences. Universidade Estadual de Santa Cruz - UESC, Ilhéus, BA, Brazil. aleschi@hotmail.com ${ }^{3}$ Universidade Federal de São Carlos - UFSCAR, Sorocaba, SP, Brazil. mcetra@ufscar.br
} 


\section{Introduction}

Human communities directly depend on natural resources for their survival and they generally have a rich knowledge of the biology and ecology of local organisms. Such knowledge, obtained through continuous interaction with their environment is considered local, traditional, or indigenous knowledge (Berkes, 1999). The scientific study of the Local Ecological Knowledge (LEK) of fishermen is a new area of investigation that integrates the efforts and interests of researchers in both natural and human sciences (Davis \& Wagner, 2003). The potential roles of this research vary from direct applications such as gathering environmental information to a more participative involvement of the community in the management of the natural resources they depend on (see Baelde, 2001). According to this author, the acceptance of local knowledge is very often limited by social and cultural barriers that stifle communication and collaboration between fishermen, scientists, and administrators as well as by the gap between science (collectively accepted by society and legitimized through objective and rigorous rules) and LEK (subjective, not tested). Numerous investigations have shown however, the importance of LEK for the conservation and management of fishing resources. Forman (1967) highlighted the importance of cognitive components in locating productive fishing areas. Mussolini (1980) described the knowledge of the "caiçaras” (fishermen) from São Paulo State concerning ecological aspects of "tainhas" (Mugil platanus). Other analyses that examined the importance of investigating folk ecological knowledge in Brazil include Begossi \& Garavello (1990), Marques (1991, 1995), Begossi \& Figueiredo (1995), Paz \& Begossi (1996), Mourão \& Nordi (2002), Silvano \& Begossi (2002), Hanazaki (2003), Huntington et al. (2004), Gerhardinger et al. (2006a, 2009), Silvano \& Jorgensen (2008), Begossi \& Silvano (2008) and Begossi (2008) including research undertaken by Costa Neto (1998), Costa Neto \& Marques (2000a, 2000b), Costa (2001), Costa Neto et al. (2002), Silvano et al. (2006), and Clauzet et al. (2007) in Bahia State. Despite the growing number of scientific work in this area there is still a lack of studies directed at the LEK of the target species of fishing, such as the Lutjanidae which are an important fishing resource through all the country's Northeast (Rezende et al., 2003), including the South of Bahia (Ibama, 2008). According to Rezende et al. (2003) the species of the group are among the most valuable fish category in the market, regarded as being a high quality fish in all states. In 2006 artiasanal fishing in Bahia yielded 33,415.5 tonnes (regarding to the exploration of more than 40 species), from this total 5,190.5 tonnes corresponded to the exploration of six species from the snapper fish group: “ariacó”, “caranha”, “cioba”, “dentão”, “guaiuba” and "vermelho” (Ibama, 2008). Among these species “cioba” (Lutjanus analis), which was the third most explored (662.5 t), is in the Red List of Threatened Species List (IUCN, 2008) categorized as being 'Vulnerable'. Up to now few studies have been made in this region about the biology, ecology and fishermen's knowledge of this species group. As such, the present research examined the Local Ecological Knowledge as well as the main criteria adopted by fishermen in Ilhéus, Bahia State, Brazil, for classifying snappers.

\section{Material and Methods}

\section{Research area}

The coast of the municipality of Ilhéus (Fig. 1) is about $80 \mathrm{~km}$ long, and the continental shelf there has a minimum width of $8 \mathrm{~km}$ (in the northern part of the municipality) and a maximum of $32 \mathrm{~km}$ near the mouth of the Pardo River (França, 1979). The region has two different patterns of oceanic circulation: "the summer pattern" and "the winter pattern". The former is characterized by the proximity of currents close to the coastline along the continental shelf, with a prevailing southward flow due to the high intensity of the currents and the greater frequency of frontal systems. The second circulation pattern is characterized by a predominant northward circulation and by lower current intensity (Rezende, 2001). The coast of Ilhéus is influenced by fresh water draining from the continent through two basins: the Cachoeira watershed (composed by the Cachoeira, Santana, and Fundão rivers) and the Almada River watershed (composed principally by this river, as well as smaller streams flowing directly into the Atlantic Ocean).

The Z19 and Z34 fishing colonies were chosen for this study due to the high numbers of fishermen living there and the consequent ease in data collection. The Z19 colony was founded in 1921 and currently has 14 boats and approximately 1500 members, although only 300 are currently active fishermen. Colony Z34 was founded in 1947 and currently has approximately 3500 active members (including people from nearby municipalities) who practice ocean and river fishing as well as shellfish harvesting.

\section{Data collection}

Data was collected between August 2005 and November 2006 during a total of 60 visits to the fishing colonies. The main collection technique employed was the semi-structured interview, employing open as well as closed questions. Free interviews were made in some cases, with questions being elaborated according to the information obtained. Visits to the fishing colonies initially occurred without any set agenda; visits were later programmed according to previsions for the arrival of the fishing boats because of the larger number of fishermen available for interviews. The interviewees were initially selected by the "specialists” criteria (Marques, 1995) - people who are considered by themselves as well as by the community as being culturally competent. The administrative employees of the colonies indicated the first specialists, these indicated others, and so on successively - the so called “snowball” method (Bailey, 1982; Silvano \& Jorgensen, 2008). When the primary interviewees were not present, interviews were opportunistically made with other individuals (Souto, 


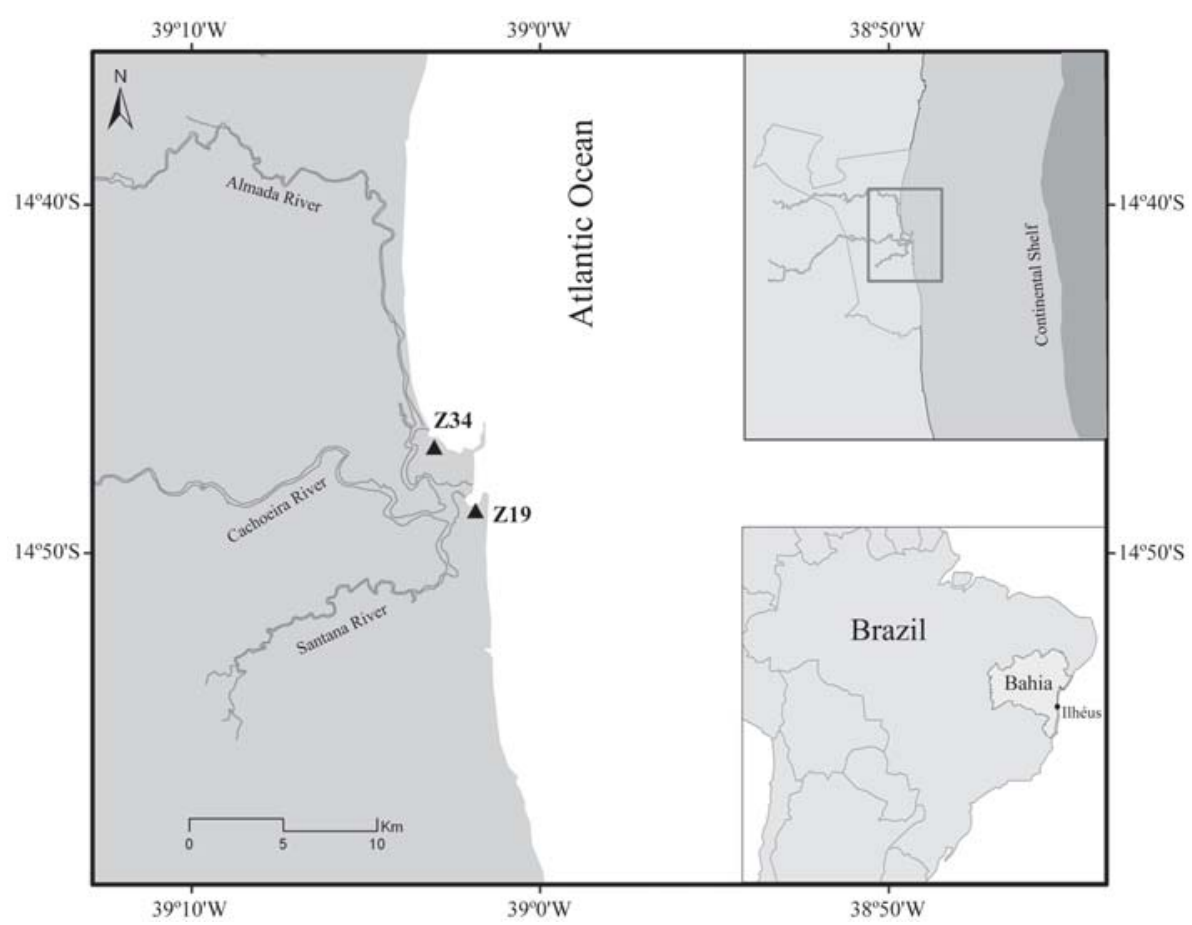

Fig. 1. Map of Bahia State, Brazil, indicating the location of the fishing colonies Z19 and Z34, continental shelf and the municipality of Ilhéus.

2007). From them, new specialists were identified and interviewed. The interviews were recorded and later transcribed, or noted simultaneously during the conversations.

Data collection was undertaken in two different stages: 32 interviews were initially made to establish a profile of the fishermen, asking questions about how long they had been associated with the colony, their source(s) of income, schooling, and whether they owned a boat. To learn more about the techniques used to capture the fish under investigation here, the fishermen were questioned about fishing tackle, bait, and the kinds of boats they used. To identify the species that are part of the snapper group questions such as "which fish do you know that are part of the snapper family?" and they were directly questioned about the feeding habits of the snapper group, "what does this fish eat?" and "which animals feed on him?", their spatial distribution: "where does this fish live?” and "at which depth does it live?", temporal distribution: "during which annual period do you fish for it?" and "at what time of the day do you usually fish it?", and reproduction: "at which time of the year does this fish reproduce and why?”. Examples of the fish were collected in the fishing colonies and identified in the laboratory of Oceanographic Biology of the Universidade Estadual de Santa Cruz. The bibliography used for identification included Figueiredo \& Menezes (1980), Menezes \& Figueiredo (1980, 1985), Lessa \& Nóbrega (2000), and Froese \& Pauly (2009). Identifications were confirmed by professor Paulo Roberto Duarte Lopes from the Universidade Estadual de Feira de Santana and the specimens were deposited on the zoological collection of the institution under the following registers: LIUEFS 10677 - Myripristis jacobus; LIUEFS 10679 - Holocentrus adscensionis; LIUEFS 10678 - Alphestes afer; LIUEFS 10685 - Cephalopholis fulva; LIUEFS 10680 - Ocyurus chrysurus; LIUEFS 10681 - Rhomboplites aurorubens; LIUEFS 10682 Lutjanus synagris; LIUEFS 10683 - Lutjanus vivanus; LIUEFS 10684 - Lutjanus jocu; LIUEFS 10686 - Pseudupeneus maculatus; LIEUFS 10687 - Priacanthus arenatus. It was not possible to collect the other species. Based on their local names, photographs of the fish mentioned were obtained from reliable sources of taxonomic classification (e.g. Froese \& Pauly, 2009) and were shown to the interviewees in order to confirm the species Paranthias furcifer (Family Serranidae), Etelis oculatus, Lutjanus analis, Lutjanus buccanella, and Lutjanus cyanopterus (Family Lutjanidae).

In the second stage, 15 fishermen from the 32 previously interviewed, were selected according to their presence and availability in the data collection points. Those 15 fishermen were questioned about the taxonomic criteria used to characterize and classify the members of the snapper group. Since it became evident, in the first stage of the study that, according to the fishermen, the fish have differences between the depth and the ocurrence environment where they are found, questions approaching these aspects were repeated individually for each species. For the Paranthias furcifer and Etelis oculatus, interviews were held at another time due to the difficulty in acquiring the pictures to confirm identification. Therefore, only seven interviews were made 
for these species due to the difficulty in finding all fishermen interviewed in the second stage. The interviews followed the projective test technique, with the interviewees being visually cued by color pictures of the species under analysis, to confirm their names and to achieve a higher level of resolution of the characteristics used to differentiate between the groups of species. The first interviews were unstructured, with open questions (such as, "how do you tell the species apart?") that would then be added to our data base, tables with morphological information were prepared using the most frequently mentioned characteristics of the fish. In later interviews, the fishermen were encouraged to indicate the presence or absence of these characters in each species.

\section{Data analysis}

Data analysis followed the unity model of the different individual (Hays, 1976 apud Marques, 1991), in which all of the information gathered in the interviews was taken into account. The data was processed following the emicist/ethicist approach, in which local knowledge is compared with that available in the scientific literature (see Marques, 1995; Silvano \& Jorgensen, 2008). Grouping analysis was made by using the number of answers from the interviewees for each species in relation to the following variables: locality of occurrence (coast, open sea, coast/open sea), depth (surface, mid-depth, mid-depth/deep, deep), coloration (eye and body color, and other particularities), and morphological aspects (body shape, fins, scales, mouth size, teeth, and eyes) of the species. Using the Pearson correlation coefficient with the data matrix constructed in an inverse, or "R" mode; the linking method used the Unweighted Pair Group Method with
Arithmetic mean (UPGMA).

\section{Results}

Most of the interviewees (87.5\%) have been working as fishermen for more than 10 years, with a variation in activity periods from 11 and up to more than 50 years (without any other source of income). All of the fishermen were living in the municipality of Ilhéus, and $25 \%$ were illiterate, $50 \%$ had started to study but had dropped out, 22\% had finished basic education, and $3 \%$ had completed their secondary education. The majority of the fishermen used boats owned by other people (75\%), and these boats were generally small (8-9 m long; maximum $12 \mathrm{~m}$ ). Fishing expeditions were usually undertaken by three or four crew members and the length of time spent at sea would depend on weather conditions and the quantity of ice that they carried. Simple hook-and -bottom line fishing tackle is used to catch snappers. The fishing colonies supply the boats with ice and fuel and provide maintenance. Their catches are sold to the colony lower than market price. According to the fishermen, the snapper group comprises of 16 species (Table 1 ).

\section{Taxonomic classification criteria}

In order to identify and distinguish the species of the snapper group, the fishermen use criteria related to their morphological aspects, such as coloration and body shape. Analyzing the similarity among the species in relation to morphological and color criteria the formation of two larger groups may be observed, which then can be subdivided into two subgroups (Fig. 2). In the first group there is a subgroup formed by the Serranidae C. fulva, L. afer and by the

Table 1. Species belonging to the snapper group according to the fishermen studied and the percentage of quotations by the handmade fishermen from Ilhéus, Bahia State, Brazil. (*) According to Froese \& Pauly (2009).

\begin{tabular}{|c|c|c|c|}
\hline Scientific nomenclature & Local names & English names ${ }^{(*)}$ & $\%$ Citation $(\mathrm{n}=32)$ \\
\hline \multicolumn{4}{|l|}{ Lutjanidae } \\
\hline Etelis oculatus (Valenciennes, 1828) & "saramonete-de-fundo" & Queen snapper & 86.6 \\
\hline Lutjanus analis (Cuvier, 1828) & “cioba” & Mutton snapper & 96.8 \\
\hline Lutjanus buccanella (Cuvier, 1828) & “boca-negra” & Blackfin snapper & 40.6 \\
\hline Lutjanus cyanopterus (Cuvier, 1828) & “caranha” & Cubera snapper & 19.0 \\
\hline Lutjanus jocu (Bloch and Schneider, 1801) & “dentão” & Dog snapper & 96.8 \\
\hline Lutjanus synagris (Linnaeus, 1758) & “ariocó” & Lane snapper & 65.6 \\
\hline Lutjanus vivanus (Cuvier, 1828) & “vermelho-do-olho-amarelo" & Silk snapper & 90.6 \\
\hline Ocyurus chrysurus (Bloch, 1791) & "guaiuba”, “rabo-aberto” & Yellowtail snapper & 37.5 \\
\hline Rhomboplites aurorubens (Cuvier, 1829) & "paramirim” & Vermilion snapper & 62.5 \\
\hline \multicolumn{4}{|l|}{ Serranidae } \\
\hline Alphestes afer (Bloch, 1793) & “sapé” & Mutton hamlet & 34.3 \\
\hline Cephalopholis fulva (Linnaeus, 1758) & “jabu” & Coney & 53.1 \\
\hline Paranthias furcifer (Valenciennes, 1828) & "mata-caboclo" & Creole-fish & 9.3 \\
\hline \multicolumn{4}{|l|}{ Holocentridade } \\
\hline Holocentrus adscensionis (Osbeck, 1765) & “jaguaraçá” & Squirrelfish & 34.3 \\
\hline $\begin{array}{l}\text { Myripristis jacobus Cuvier, } 1829 \\
\text { Priachantidae }\end{array}$ & “cu-de-galinha”, “cu-de-pinto” & Blackbar soldierfish & 86.6 \\
\hline $\begin{array}{l}\text { Priacanthus arenatus Cuvier, } 1829 \\
\text { Mullidae }\end{array}$ & "olhão”, “olho-de-vidro”, “piranema” & Atlantic bigeye & 25.0 \\
\hline Pseudupeneus maculatus (Bloch, 1793) & "saramonete" & Spotted goatfish & 31.3 \\
\hline
\end{tabular}


Priacanthidae $P$. arenatus. Characteristics that were present in most answers for the group were "small teeth", "closed caudal fin” (closed tail), “dark scales”, “dark belly”, “dark red" and "red eyes” (Tables 2 and 3). The Serranidae pair also has in common the "small eyes" characteristic, unlike $P$.

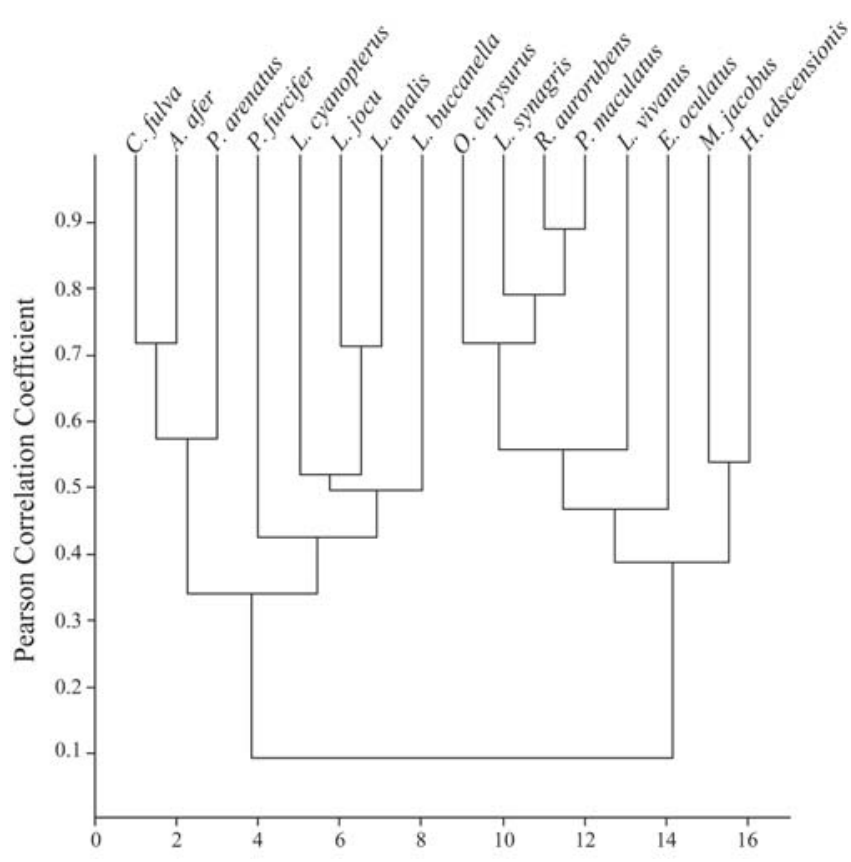

Fig. 2. Similarity dendogram for the morphologic and color criteria used by the interviewed fishermen from Ilhéus, Bahia State, Brazil, to classify the species of the snapper group (number of interviews $=15$; for the $E$. oculatus and $P$. furcifer $\mathrm{n}=7)$. arenatus that, according to most interviewees, has "big eyes" (Table 2). In the first group, it may be observed that there is a formation of yet another subgroup with the species $P$. furcifer and the lutjanids $L$. cyanopterus, $L$. jocu, L. analis and $L$. buccanella. According to most interviewees, all these species have "smooth scales" and are "dark", they have a "light belly" and are considered to be "dark red" and have "small eyes" (Tables 2 and 3). Lutjanids also have in common the characteristic of a "closed caudal fin" unlike $P$. furcufer that have an "open caudal fin” (Table 2).

In the second group, a subgroup with the three Lutjanidae $O$. chrysurus, $L$. synagris, $R$. aurorubens and the Mullidae $P$. maculatus is noticed. The common features for these species were: "small teeth", "smooth scales" and "light” colouring, "narrow body”, "small eyes”, "light belly”, being considered as "light red" and "red eyes" (Tables 2 and 3). Still in this subgroup the characteristic "yellow strip" was present in $100 \%$ of the answers for all the species, with the exception of $R$. aurorubens (Table 3). Another subgroup was formed by the Holocentridae pair M. jacobus and $H$. adscensionis. Most of the answers for these species were "small mouth”, "small teeth”, “long caudal fin” ("long tail”) and "open”, "big eyes", "light scales", "light belly" and "light red” (Tables 2 and 3).

\section{Local Ecological Knowledge: Prey and predators}

The fishermen (100\%) considered snappers to be carnivorous and in fact, the majority of the species analyzed in this study were classified as piscivorous. In addition to fish, other groups were mentioned, such as crustaceans and shellfish. In addition to being carnivorous, $M$. jacobus, $P$. maculatus, and $H$. adscensionis were identified as consuming

Table 2. Main morphological characteristics mentioned by fishermen to classify the integrants of the snapper group with the respective number of obtained answers (number of interviews $=15$; for the $E$. oculatus and $P$. furcifer $\mathrm{n}=7$ ). $\mathrm{LM}=$ large mouth, $\mathrm{SM}=$ small mouth, $\mathrm{BT}=$ big teeth, $\mathrm{ST}=$ small teeth, $\mathrm{SS}=$ smooth scales, $\mathrm{SHS}=$ sharp scales, $\mathrm{NB}=$ narrow body, $\mathrm{LB}=$ large body, SCF = short caudal fin, LCF = long caudal fin, CCF = "closed" caudal fin, OCF = "open" caudal fin, BE = big eye, SE = small eye.

\begin{tabular}{|c|c|c|c|c|c|c|c|c|c|c|c|c|c|c|}
\hline & \multicolumn{14}{|c|}{ Morphological characteristics } \\
\hline & LM & SM & BT & ST & SS & SHS & NB & LB & SCF & LCF & CCF & OCF & $\mathrm{BE}$ & SE \\
\hline Alphestes afer & 2 & 13 & 0 & 15 & 15 & 0 & 0 & 15 & 13 & 2 & 15 & 0 & 0 & 15 \\
\hline Cephalopholis fulva & 15 & 0 & 0 & 15 & 15 & 0 & 0 & 15 & 11 & 4 & 15 & 0 & 0 & 15 \\
\hline Etelis oculatus & 7 & 0 & 0 & 7 & 7 & 0 & 7 & 0 & 6 & 1 & 0 & 7 & 5 & 2 \\
\hline Holocentrus adscensionis & 0 & 15 & 0 & 15 & 0 & 15 & 15 & 0 & 0 & 15 & 0 & 15 & 15 & 0 \\
\hline Lutjanus analis & 0 & 15 & 0 & 15 & 15 & 0 & 4 & 11 & 3 & 12 & 15 & 0 & 0 & 15 \\
\hline Lutjanus buccanella & 9 & 6 & 0 & 15 & 15 & 0 & 4 & 11 & 6 & 9 & 15 & 0 & 0 & 15 \\
\hline Lutjanus cyanopterus & 12 & 3 & 15 & 0 & 15 & 0 & 10 & 5 & 13 & 2 & 15 & 0 & 0 & 15 \\
\hline Lutjanus jocu & 3 & 12 & 15 & 0 & 15 & 0 & 3 & 12 & 7 & 8 & 15 & 0 & 0 & 15 \\
\hline Lutjanus synagris & 8 & 7 & 0 & 15 & 15 & 0 & 15 & 0 & 3 & 12 & 15 & 0 & 0 & 15 \\
\hline Lutjanus vivanus & 1 & 14 & 13 & 2 & 15 & 0 & 15 & 0 & 11 & 4 & 15 & 0 & 0 & 15 \\
\hline Myripristis jacobus & 0 & 15 & 0 & 15 & 15 & 0 & 5 & 10 & 0 & 15 & 3 & 12 & 15 & 0 \\
\hline Ocyurus chrysurus & 0 & 15 & 0 & 15 & 15 & 0 & 11 & 4 & 0 & 15 & 0 & 15 & 0 & 15 \\
\hline Paranthias furcifer & 1 & 6 & 6 & 1 & 7 & 0 & 7 & 0 & 0 & 7 & 0 & 7 & 2 & 5 \\
\hline Priacanthus arenatus & 15 & 0 & 3 & 11 & 15 & 0 & 3 & 12 & 0 & 15 & 15 & 0 & 15 & 0 \\
\hline Pseudupeneus maculatus & 0 & 15 & 0 & 15 & 15 & 0 & 15 & 0 & 12 & 3 & 15 & 0 & 0 & 15 \\
\hline Rhomboplites aurorubens & 0 & 15 & 0 & 15 & 15 & 0 & 11 & 4 & 5 & 10 & 15 & 0 & 0 & 15 \\
\hline
\end{tabular}


Table 3. Main criteria related to the color used by fishermen to classify integrants of the snapper group with the respective number of obtained answers (number of interviews $=15$; for the $E$. oculatus and $P$. furcifer $\mathrm{n}=7$ ). $\mathrm{YS}=$ yellow strip, $\mathrm{BS}=$ blue strip, DSBS = dark spot on body side, DSPF = dark spot on pectoral fin, $\mathrm{BD}=$ black dots, $\mathrm{YD}=$ yellow dots, $\mathrm{DS}=$ dark scales, $\mathrm{LS}=$ light scales, $\mathrm{LB}=$ light belly, $\mathrm{DB}=$ dark belly, $\mathrm{DR}=$ dark red, $\mathrm{LR}=$ light red, $\mathrm{YE}=$ yellow eye, $\mathrm{DE}=$ dark eye, $\mathrm{BE}$ = black eye.

\begin{tabular}{|c|c|c|c|c|c|c|c|c|c|c|c|c|c|c|c|}
\hline & \multicolumn{15}{|c|}{ Color criteria } \\
\hline & YS & BS & DSBS & DSPF & $\mathrm{BD}$ & YD & DS & LS & LB & VE & DB & DR & LR & YE & $\mathrm{BE}$ \\
\hline Alphestes afer & 0 & 0 & 0 & 0 & 0 & 15 & 14 & 1 & 0 & 15 & 15 & 0 & 0 & 12 & 3 \\
\hline Cephalopholis fulva & 0 & 0 & 0 & 0 & 15 & 0 & 15 & 0 & 0 & 15 & 15 & 0 & 0 & 13 & 2 \\
\hline Etelis oculatus & 0 & 0 & 0 & 0 & 0 & 7 & 7 & 0 & 1 & 6 & 0 & 7 & 0 & 0 & 0 \\
\hline Holocentrus adscensionis & 10 & 0 & 0 & 0 & 0 & 0 & 4 & 11 & 15 & 0 & 0 & 15 & 0 & 2 & 13 \\
\hline Lutjanus analis & 0 & 15 & 15 & 0 & 0 & 0 & 12 & 3 & 15 & 0 & 15 & 0 & 0 & 12 & 3 \\
\hline Lutjanus buccanella & 0 & 0 & 0 & 15 & 0 & 0 & 15 & 0 & 15 & 0 & 15 & 0 & 15 & 0 & 0 \\
\hline Lutjanus cyanopterus & 0 & 0 & 0 & 0 & 0 & 0 & 15 & 0 & 15 & 0 & 15 & 0 & 0 & 1 & 14 \\
\hline Lutjanus jocu & 0 & 15 & 0 & 0 & 0 & 0 & 15 & 0 & 15 & 0 & 15 & 0 & 0 & 12 & 3 \\
\hline Lutjanus synagris & 15 & 0 & 15 & 0 & 0 & 0 & 3 & 12 & 15 & 0 & 0 & 15 & 0 & 13 & 2 \\
\hline Lutjanus vivanus & 0 & 0 & 0 & 0 & 0 & 0 & 0 & 15 & 15 & 0 & 0 & 15 & 15 & 0 & 0 \\
\hline Myripristis jacobus & 0 & 0 & 0 & 15 & 0 & 0 & 0 & 15 & 15 & 0 & 0 & 15 & 0 & 13 & 2 \\
\hline Ocyurus chrysurus & 15 & 0 & 0 & 0 & 0 & 0 & 0 & 15 & 15 & 0 & 0 & 15 & 0 & 13 & 2 \\
\hline Paranthias furcifer & 0 & 0 & 0 & 0 & 7 & 0 & 7 & 0 & 7 & 0 & 0 & 7 & 0 & 0 & 0 \\
\hline Priacanthus arenatus & 0 & 0 & 0 & 0 & 0 & 0 & 15 & 0 & 0 & 15 & 15 & 0 & 0 & 13 & 2 \\
\hline Pseudupeneus maculatus & 13 & 0 & 0 & 0 & 0 & 0 & 0 & 15 & 15 & 0 & 0 & 15 & 0 & 14 & 1 \\
\hline Rhomboplites aurorubens & 0 & 0 & 0 & 0 & 0 & 0 & 2 & 13 & 15 & 0 & 0 & 15 & 0 & 13 & 2 \\
\hline
\end{tabular}

"small rocks", seaweed, mud and spawn. The main predators mentioned were the horse-eyed Seriola sp. (Carangidae Family), the Ephinephelus sp. (Serranidae Family), the sea bass Mycteroperca sp. (Serranidae Family) and the Carcharias sp., according to their local names.

\section{Spatial distribution}

In terms of their spatial distribution, it was possible to establish that there are both horizontal (places of occurrence) and vertical (depth) variations among the analyzed species. The fishermen divided the species into those that "live in the river as well as in the sea" and those that live only in the sea; however, these can stay near the coast, being called "coastal fish", or frequent areas further from the coast, being considered "offshore fish". A majority of the interviewees considered $L$. cyanopterus to be a fish that could be found in "rivers as well as in the sea" (Table 4). The species considered "coastal" were L. synagris, $C$. fulva, $M$. jacobus, $H$. adscensionis, and $P$. arenatus (Table $4)$. The rest of the species were considered by most of the fishermen to be "offshore" fish (Table 4). In the correlation analysis, groups were formed according to their places of occurrence (Fig 3).

The species were also categorized by the depth at which they were usually captured, being classified as "shallow fish" (captured up to $20 \mathrm{~m}$ deep), "mid-depth fish" (at depths between 20 to $60 \mathrm{~m}$ ), “deep-water fish” (deeper than $60 \mathrm{~m}$ ), and "mid- and deep-water fish" (that could be captured at both depths). The following species were considered "middepth" fish: L. cyanopterus, L. jocu, L. synagris, L. analis, O. chrysurus, C. fulva, A. afer, P. maculatus, M. jacobus, and $P$. arenatus (Table 5). The species considered "mid- and deepwater" were $L$. vivanus and $L$. buccanella (Table 5). The
Table 4. Occurence environment mentioned for the snapper group according to interviewees with the respective number of obtained answers (number of interviews $=15$; for the $E$. oculatus and $P$. furcifer $\mathrm{n}=7$ ).

\begin{tabular}{lccc}
\hline & \multicolumn{3}{c}{ Ocurrence environment } \\
& River and sea & Close to the shore & "High sea" \\
\hline Alphestes afer & 0 & 5 & 10 \\
Cephalopholis fulva & 0 & 14 & 1 \\
Etelis oculatus & 0 & 0 & 7 \\
Holocentrus adscensionis & 0 & 15 & 0 \\
Lutjanus analis & 0 & 6 & 9 \\
Lutjanus buccanella & 0 & 3 & 12 \\
Lutjanus cyanopterus & 8 & 5 & 2 \\
Lutjanus jocu & 0 & 5 & 10 \\
Lutjanus synagris & 0 & 15 & 0 \\
Lutjanus vivanus & 0 & 2 & 13 \\
Myripristis jacobus & 0 & 13 & 2 \\
Ocyurus chrysurus & 0 & 5 & 10 \\
Paranthias furcifer & 0 & 0 & 7 \\
Priacanthus arenatus & 0 & 14 & 1 \\
Pseudupeneus maculatus & 0 & 4 & 11 \\
Rhomboplites aurorubens & 0 & 4 & 11 \\
\hline
\end{tabular}

species found deeper than 60 meters included $E$. oculatus, $P$. furcifer, and $H$. adscensionis (Table 5). In the correlation analysis the species were grouped according to their depths (Fig 4).

\section{Temporal distribution}

According to $87 \%$ of the fishermen interviewed, snappers are mostly captured in winter - being considered "winter fish". The rest of the fishermen indicated that these fish could be captured all year round, and they do not appear to have a particular period of activity. During the summer 


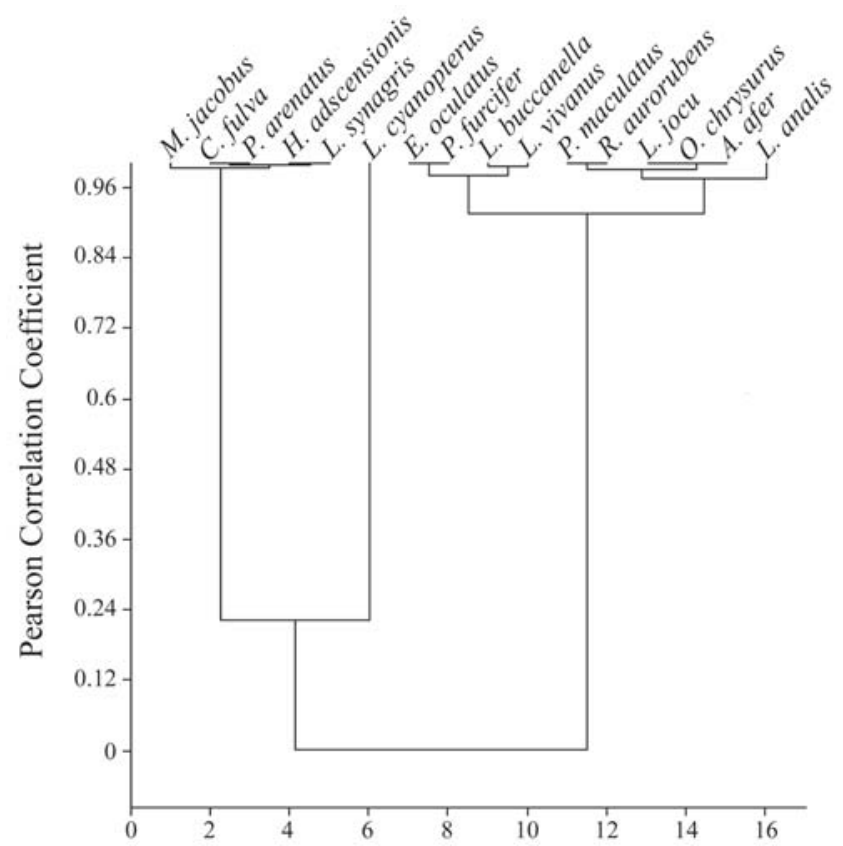

Fig. 3. Similarity dendrogram for the species of the snapper group according to the environments in which they are found, according to the perception of the fishermen from Ilhéus, Bahia State, Brazil (number of interviews = 15; for the $E$. oculatus and $P$. furcifer $\mathrm{n}=7$ ).

Table 5. Depths inhabited by the snapper group according to interviewees with the respective number of obtained answers (number of interviews $=15$; for the $E$. oculatus and $P$. furcifer $\mathrm{n}=7)$.

\begin{tabular}{lcccc}
\hline & \multicolumn{4}{c}{ Depth (m) } \\
& up to 20 & 20 to a 60 & 20 up to 60 & $>60$ \\
\hline Alphestes afer & 1 & 14 & 0 & 0 \\
Cephalopholis fulva & 0 & 10 & 4 & 1 \\
Etelis oculatus & 0 & 0 & 0 & 7 \\
Holocentrus adscensionis & 0 & 0 & 1 & 14 \\
Lutjanus analis & 0 & 13 & 2 & 0 \\
Lutjanus buccanella & 0 & 0 & 15 & 0 \\
Lutjanus cyanopterus & 1 & 13 & 1 & 0 \\
Lutjanus jocu & 0 & 14 & 1 & 0 \\
Lutjanus synagris & 1 & 14 & 0 & 0 \\
Lutjanus vivanus & 0 & 0 & 15 & 0 \\
Myripristis jacobus & 1 & 11 & 3 & 0 \\
Ocyurus chrysurus & 0 & 11 & 4 & 0 \\
Paranthias furcifer & 0 & 0 & 3 & 4 \\
Priacanthus arenatus & 0 & 12 & 0 & 3 \\
Pseudupeneus maculatus & 2 & 11 & 2 & 0 \\
Rhomboplites aurorubens & 5 & 5 & 4 & 1 \\
\hline
\end{tabular}

(December to April) the tides run fast ("maré corre muito"), while the winter period is defined as a time when the tide slows ("maré para") and it is easier to capture fish that are usually found at greater depths. As such, "winter fish" define a period of greater abundance, but not a period of higher production. According to this information the

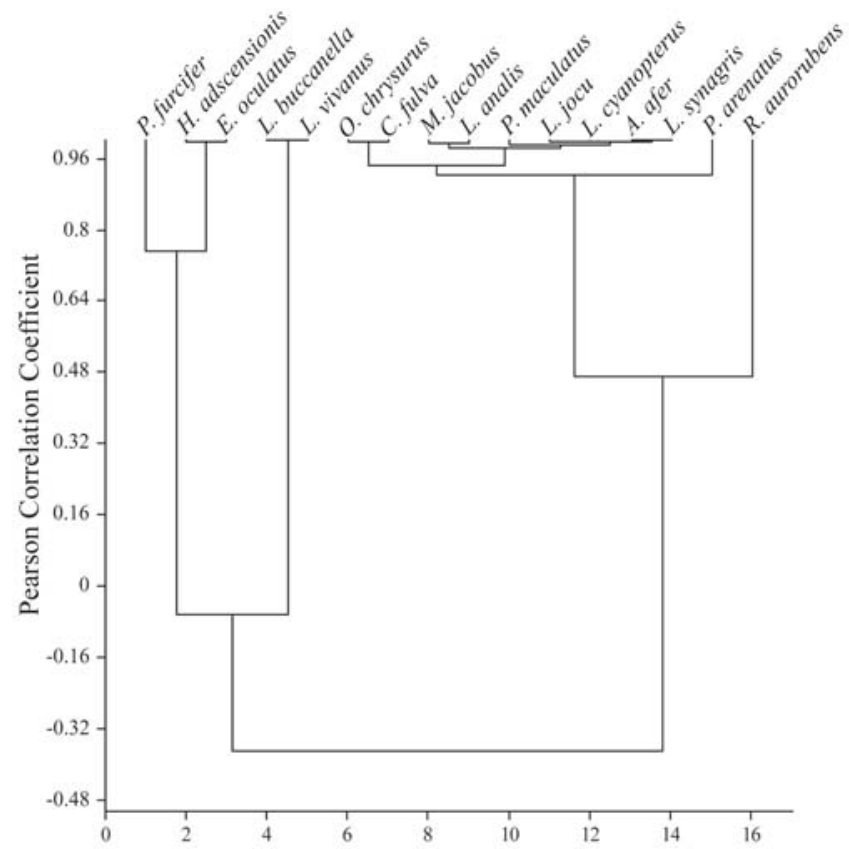

Fig. 4. Similarity dendrogram for the species of the snapper group according to the depth at which they are found, according to the fishermen from Ilhéus, Bahia State, Brazil (number of interviews $=15$; for the E.oculatus and $P$. furcifer $n=7)$.

fishermen consider that there is no variation when it comes to the abundance of animals throughout the year, what happens is that it becomes easier to catch more of them in the summer.

Fifty three percent of the interviewees indicated that more fish were caught "in the early morning and in the early afternoon", while approximately 31\% indicated the night period, $15 \%$ at any time of the day or night, and $3 \%$ in the evening period.

\section{Reproduction}

Fifty six percent of the interviewees considered themselves unable to respond to questions about reproduction. The other interviewees gave diverse and unrelated answers. Some fishermen ( $n=3$; fishing period $>20$ years) referred to the "ribada period" as the moment in which the snappers reproduce, and they presented two different versions. In the first (mentioned by two fishermen), the "ribada period" taked place between March and April and the fish "go up and go to the surface to feed and spawn, they are hungry due to spawning and go up to feed". This affirmation was based on the capture of spawning individuals during this period. In the second version (mentioned by a single fisherman), the "ribada period" taked place during the winter, and relates the abundance of fish with their reproduction, as in the following quotation: "there are a lot of fish, they gather there and from that shoal, more fish appear”. Another fisherman indicated that the reproductive period of the fish 
is related to their body size, and that some species "get fat when they are producing spawn”.

\section{Discussion}

Most of the fishermen in this study have profiles similar to those reported for other regions in Bahia State and even in other parts of the country (see Camargo \& Petrere Jr., 2001; Garcez \& Sánchez-Botero, 2005; Clauzet et al., 2005, 2007; Pacheco, 2006). As such, it is very difficult to retrain fishermen for other activities and this impedes them in attempts to obtain resources to improve the productivity of the fishing industry. One factor that can influence low education levels among fishermen is their easy access to food resources and despite using motorized boats their lifestyle can be considered as non-mechanized. Generally, the species considered to be snappers belong only to the family Lutjanidae (Menezes \& Figueiredo, 1980; Cervigón, 1993; Lessa \& Nobrega, 2000; Froese \& Pauly, 2009). The factors that justified the inclusion of other families into this group in the present study are related to morphological criteria (such as coloration and body form) that are purely local. Many of these criteria are found in guides and in taxonomic identification keys (Menezes \& Figueiredo, 1980; Figueiredo \& Menezes, 1980; Lessa \& Nobrega, 2000). Criteria related to color appeared to be more used by the interviewees, particularly to differentiate the species; those related with other morphologic aspects are used as additional criteria. Coloration can be considered a very simplified factor, especially when compared with identifications based on the numbers of stripes, spines, membranes, or internal structures - criteria usually employed in the Linnean taxonomy (Menezes \& Figueiredo, 1980; Lessa \& Nóbrega, 2000). According to Mourão \& Nordi (2002) coloration, body shape (or a peculiar feature related to it), the size of the organism or a body part, and the kinds of scales and fins are morphological details widely used in local classification systems. These same characteristics were reported by other authors in studies with traditional fishermen in different coastal and estuarine localities in Brazil, such as in Piratininga, Rio de Janeiro State (Silva, 1989); Baia de Sepetiba, Rio de Janeiro State (Paz \& Begossi, 1996); Mundaú-Manguaba in Alagoas State (Marques, 1991); the Municipality of Conde, Bahia State (Costa Neto, 1998); and
Praia do Forte, Bahia State (Grando, 2003). Comparing both classification systems (local and Linnean) species did not form closed groups in accordance to their correspondent scientific families (see Fig. 2), even if groups were formed with species from the same family. Based on this result it can be stated that the criteria adopted by the fishermen is based only in the similarity and evidence of external morphologic aspects of the species. This would justify the mixing of species of five scientific families into just one group. There may be cases in which some fishermen consider unique scientific species as two or more local species, due to factors such as occurrence environment, ontogenesis, morphology and even physiologic ("strong smell", for instance). On Mourão \& Nordi (2002) study Mugil curema species is considered as two local species according to fishermen from the river Mamanguape (PB) estuary: "tainha do zoi preto" (black eyed mullet) and "tainha do zoi vermelho" (red eyed mullet). In this same study, three species of the Anchoa genre are considered as just one local species: the "white sardine". This type of result may lead to taxonomic confusions that hinder the data analysis, especially when it is not possible to collect specimens for scientific identification of the species. In this study the 1:1 correspondence observed between the folk and scientific classification systems shows a concrete detailing of species identification and distinctions and demonstrates that the identifications made by fishermen can supply consistent data concerning rich fishing resources and that they can be useful in the description of new species.

The large amount of information that can be collected through LEK analysis is the result of local economic reliance on snapper fishing. These fishermen must know the habits and behavior of these species and be able to detect the best periods, times and strategies in order to maximize their harvest. Most of the information gathered here that refers to feeding coincides with data available in scientific literature (see Table 6).

Sometimes there is disagreement between LEK and the information from ichthyologic literature - but when this happens, it offers the opportunity for more detailed scientific investigation (Johannes \& Hviding, 2000; Silvano, 2001, 2004). According to Silvano (2004), one aspect of fish biology best known to the local fishermen are their trophic interactions, and trophic models made according to local

Table 6. Comparison between Local Ecological Knowledge (LEK) and scientific knowledge referring to the feeding habits of the snapper group species.

\begin{tabular}{|c|c|c|}
\hline Scientific Family & LEK & Ichthyological Literature \\
\hline Lutjanidae & small fish and shrimp & carnivores ( Lowe-McConnell, 1999; Ferreira et al., 2004; Floeter et al., 2006; Medeiros et al., 2007) \\
\hline Serranidae & small fish and shrimp & carnivores (Lowe-McConnell, 1999) \\
\hline Priacanthidae & small fish and shrimp & carnivores (Floeter et al., 2006) \\
\hline Mullidae & $\begin{array}{l}\text { "small rocks", seaweed, } \\
\text { mud, spawn and small fish }\end{array}$ & $\begin{array}{l}\text { zooplankton, mobile-invertebrate, and small fish (Ferreira et al., 2004; Floeter et al., 2006; Medeiros et al., 2007; } \\
\text { Froese \& Pauly, 2009) }\end{array}$ \\
\hline Holocentridae & $\begin{array}{l}\text { "small rocks", seaweed, } \\
\text { mud, spawn and small fish }\end{array}$ & carnivores, mobile-invertebrate (Floeter et al., 2006) \\
\hline
\end{tabular}


knowledge has been shown as compatible with biological models (Marques, 1991, 1995; Silvano, 2001; Silvano \& Begossi, 2002). Marques (1995) reported very detailed knowledge about the trophic ecology of the fish among the Marituban fishermen (Alagoas State, Brazil). In a study undertaken by Thé \& Nordi (2006) in the upper-middle São Francisco River, the fishermen there demonstrated a high level of knowledge about the trophic ecology of fish, including information about "what fish feed on" and "what preys on them". In this analysis, the fishermen also mentioned possible predators of the fish examined here. Species from the Carangidae and Serranidae families are usually predators and fish is often included in their diets (Menezes \& Figueiredo, 1980) - supporting information supplied here by the fishermen. According to Vasconcellos \& Gasalla (2001) and Silvano (2004), information about the food chains of sea animals can aid in the management of fishing activities and in the evaluation of aquatic eco-system productivity.

Detailed knowledge related to the spatial distribution of fish is decisive in choosing fishing strategies and assuring a good catch and the importance of this knowledge to fishing activities is mentioned by numerous authors (Marques, 1991; Paz \& Begossi, 1996; Thé \& Nordi, 2006; Mourão \& Nordi, 2006). In terms of the places where the fish occur, LEK evaluations prove to be generally very similar to those reported in the biological literature. Authors such as Figueiredo \& Menezes (1980) use terms like "fresh water", "estuaries", "coastal waters" and "oceanic waters" or "waters further from the coast" - which correspond with what fishermen call "river", "river and sea”, "coastal” and "offshore", respectively. The fishermen interviewed by Mourão \& Nordi (2006) also classify fish into "offshore" and "coastal". The fishermen from Barra do Una (Peruíbe/ SP) studied by Clauzet et al. (2005) also differentiate fish according to the habitats in which they live: "sea fish", "river fish", "fen fish", "fresh water fish", "pond fish" and "sea and river fish”. According to Marques (1991), classifications based on habitat have been found by different authors in many different cultures. Another study undertaken by Gerhardinger et al. (2006a) reported the localities of occurrence of Epinephelus itajara in the Baia de Babitonga (SC). However, in comparing the data obtained in the present study with the specialized literature, it was seen that local knowledge of the localities of occurrence of L. cyanopetrus, the $L$. jocu, and the $P$. maculatus were not consistent, which were considered as coastal species (Figueiredo \& Menezes, 1980; Lessa \& Nobrega, 2000).

Similar terminologies to those reported here for categorizing fish in the water column were found in studies such as Marques (1991), Costa Neto (1998), Costa Neto \& Marques (2000b), Thé \& Nordi (2006), and Mourão \& Nordi (2006). With the exception of the information supplied for $M$. jacobus, $L$. analis, and $P$. arenatus, LEK was very similar to the scientific literature (Figueiredo \& Menezes, 1980; Cervigòn, 1993; Lessa \& Nobrega, 2000). These three species, considered by the fishermen as "mid-water" inhabitants, were considered by the authors mentioned above as deep-water fish. The majority of the species known as the Lutjanidae family, live at considerable depths (up to 650 meters), although some of them frequent estuaries and even fresh water bodies (Figueiredo \& Menezes, 1980). A study with lutjanids in northeastern Brazil indicated that smaller individuals are usually found in shallow coastal waters, while the largest individuals are found in deeper regions (Frédou \& Ferreira, 2005). Thompson \& Mumot (1978) reported that larger individuals of serranids are found in deeper portions of the Caribbean Sea. The differences found between the information furnished by the local fishermen and that reported in the specialized literature indicates that the fisherman usually associate these fish with their main habits, but this does not imply that their occurrence is exclusive to that habitat or depth (Mourão \& Nordi, 2006).

When mentioning "winter fish", the fishermen are not referring to a period of higher abundance, but to the period of higher fishing production. Souto (2007) found that the period in which there is "more seafood" is also a time of higher production. In other studies, the fishermen classified winter and summer periods according to different criteria, such as the transparency of the water (Mourão \& Nordi, 2006). In her study of the fishermen from the floodplain of the upper Paraná River, Carvalho (2002) found that the period in which there is a higher abundance of fish is related to their reproduction in the rainy season. Marques (1991) defined the fishermen's perception of the daily routines of fish as "informal time units", and reported the use of 13 units, including those mentioned in this present study: "in the early morning", "in the early afternoon", "in the afternoon" and "in the evening". Hobson (1975) apud LoweMcConnell (1999) studying coral reef fish in Hawaii, concluded that holocentrids, serranids, priacantids, and lutjanids are exclusively night-time and twilight feeders.

The lack of knowledge about the details of fish reproduction by the majority of the fishermen in the present study may be explained by the fact that they do not handle the fish very often, selling them whole to middlemen (fishing colonies) and not directly to the consumer. As such, the fishermen do not need to open, gut, or clean the fish and do not routinely inspect their gonads. This hypothesis is reinforced by statements such as "just by opening I can tell you, with eggs: female", "if by opening there are no eggs, I am not sure whether it is a male or female". This conclusion is supported by Gerhardinger et al. (2006a) who suggested that the lack of self-confidence in the answers given by the interviewees is related to the fact that they do not look at the guts of the fish sold directly to the local markets. One statement by a fisherman relates the abundance of the fish with their reproduction "there is a lot of fish, they gather there, and from that shoal, more of them can be caught". This reproductive behavior can be linked with the schools formed in the reproductive season by some species of the 
Lutjanidae and Serranidae families (Menezes \& Figueiredo, 1980; Figueiredo \& Menezes, 1980; Andrade, 2003; Gerhardinger et al., 2006a, 2006b). More specific studies are therefore needed to verify the authenticity of this information, since the identification and protection of reproductive areas can be efficient management strategies, especially in light of the fact that many of the species analyzed are often commercially exploited beyond sustainable limits. The increase in the body size of these fish during their reproductive period was also reported by Gerhardinger et al. (2006a). Local information from other studies of the reproductive periods of fish was seen to be very detailed, such as that provided by the fishermen from the floodplain of the upper Paraná River (Carvalho, 2002) and the fishermen from upper-middle São Francisco River (Thé \& Nordi, 2006), as well as in the work by Silvano et al. (2006) who analyzed local knowledge of the reproduction of the principal fish sold by fishermen distributed along the coast of Brazil.

Much of the information mentioned in the present study agrees with the specialized literature - reinforcing the importance of linking LEK with scientific knowledge and decision making processes. Some of the information that was gathered could not be confirmed in the specialized literature, suggesting new lines of investigation into the habits and behavior of the species examined.

\section{Acknowledgements}

The authors would like to thank the "Fundação de Amparo à Pesquisa do Estado da Bahia” for the Masters degree scholarship; the graduate program in Zoology of the "Universidade Estadual de Santa Cruz" for their support; to Professor Paulo Roberto Duarte Lopes and "Universidade Estadual de Feira de Santana" - Laboratory of Ichthyology; to Leonardo dos Santos of the Z-19 fishing colony and Márcio Batista of the Z-34 fishing colony for their assistance during our field activities; and all the fishermen whose information and help made this study possible.

\section{Literature Cited}

Andrade, F. M. 2003. A comparison of life histories and ecological aspects among snappers (Pisces: Lutjanidae). Unpublished Dissertation, Graduate Faculty of the Louisiana State University and Agricultural and Mechanical College, 194p.

Baelde, P. 2001. Using Fishers’ Knowledge Goes Beyond Filling Gaps in Scientific knowledge - Analysis of Australian Experiences. Putting Fishers' Knowledge to Work. University of British Columbia, Florida Center for Reading Research, Pp. 78-86.

Bailey, K. D. 1982. Methods of social research. New York, McMillan Publishers, The Free Press, 553p.

Begossi, A. 2008. Local knowledge and training towards management. Environment, Development and Sustainability, 10: 591-603.

Begossi, A. \& J. L. Figueiredo. 1995. Ethnoichthyology of southern coastal fishermen: cases from Búzios Island and Sepetiba Bay (Brazil). Bulletin of Marine Science, 56(2): 682-689.
Begossi, A. \& J. C. Garavello. 1990. Notes on the ethnoichthyology of fishermen from the Tocantins River (Brazil). Acta Amazônica, 20: 341-351.

Begossi, A. \& R. A. M. Silvano. 2008. Ecology and ethnoecology of dusky grouper [garoupa, Epinephelus marginatus (Lowe, 1834)] along the coast of Brazil. Journal of Ethnobiology and Ethnomedicine, 4: 20.

Berkes, F. 1999. Sacred Ecology: Traditional ecological Knowledge and resource management. Philadelphia, Taylor \& Francis, 209p.

Camargo, S. A. F. \& M. Petrere Jr. 2001.Social and financial aspects of the artisanal fisheries of Middle São Francisco River, Minas Gerais, Brazil. Fisheries Management and Ecology, 8: 163171.

Carvalho, A. R. 2002. Conhecimento ecológico no ‘varjão’ do alto rio Paraná: alterações antropogênicas expressas na linguagem dos pescadores. Acta Scientiarum, 24(2): 581-589.

Cervigón, F. 1993. Los peces marinos de Venezuela. Volume 2. Caracas, Fundación Científica Los Roques, 497p.

Clauzet, M., M. Ramires \& W. Barrella. 2005. Pesca Artesanal e Conhecimento Local de duas Populações Caiçaras (Enseada do Mar Virado e Barra do Una) no Litoral de São Paulo, Brasil. Multiciência, 4: 1-22.

Clauzet, M., M. Ramires \& A. Begossi. 2007. Etnoecologia dos pescadores artesanais da praia de Guaibim, Valença (BA), Brasil. Neotropical Biology and Conservation, 2(3): 136-154.

Costa, R. C. S. 2001. Etnoecologia dos pescadores da comunidade de Vila Cachoeira, Ilhéus, Sul da Bahia, Brasil. Unpublished Monograph (Ciências Biológicas), Universidade Estadual de Santa Cruz, 93p.

Costa Neto, E. M. 1998. Etnoictiologia, desenvolvimento e sustentabilidade no litoral norte baiano. Um estudo de caso entre os pescadores do município de Conde. Unpublished MSc. Dissertation, Universidade Federal de Alagoas, Maceió, 191p.

Costa Neto, E. M., C. V. Dias \& M. N. Melo. 2002. O conhecimento ictiológico tradicional dos pescadores da cidade de Barra, região do médio rio São Francisco, estado da Bahia, Brasil. Acta Scientiarum, 24(2): 561-572.

Costa Neto, E. M. \& J. G. W. Marques. 2000a. A etnotaxonomia de recursos ictiofaunísticos pelos pescadores da comunidade de Siribinha, norte do estado da Bahia, Brasil. Biociências, 8(2): 61-76.

Costa Neto, E. M. \& J. G. W. Marques. 2000b. Conhecimento ictiológico tradicional e distribuição temporal e espacial de recursos pesqueiros pelos pescadores de Conde, Estado da Bahia, Brasil. Etnoecológica, 4(6): 56-67.

Davis, A. \& J. R. Wagner. 2003. Who knows? On the importance of identifying "experts” when researching local ecological knowledge. Human Ecology, 31(3): 463-489.

Ferreira, C. E. L., S. R. Floeter, J. L. Gasparini, B. P. Ferreira \& J. C. Joyeux. 2004. Trophic structure patterns of Brazilian reef fishes: a latitudinal comparison. Journal of Biogeography, 31(7): 1093-1106.

Figueiredo, J. L. \& N. A. Menezes. 1980. Manual de peixes marinhos do sudeste do Brasil: III. Teleostei. v. 2. São Paulo, Museu de Zoologia da USP, 90p.

Floeter, S. R., B. S. Halperna \& C. E. L. Ferreira. 2006. Effects of fishing and protection on Brazilian reef fishes. Biological Conservation, 128: 391-402.

Forman, S. 1967. Cognition and the catch: the location of fishing spots in a Brazilian coastal village. Ethnology, 6(4): 417-426. 
França, A. M. C. 1979. Geomorfologia da margem continental Leste brasileira e da bacia oceânica adjacente. Série Projeto REMAC, 7: 92-123.

Fredou, T. \& B. P. Ferreira. 2005. Bathymetric trends of northeastern Brazilian snappers (Pisces, Lutjanidae): implications for the reef fishery dynamic. Brazilian Archives of Biology and Technology, 48(5): 787-800.

Froese, R. \& D. Pauly. 2009. FishBase. World Wide Web electronic publication (Version 01/2009). Available at: www.fishbase.org. Accessed in March 2009.

Garcez, D. S. \& J. I. Sánchez-Botero. 2005. Comunidades de pescadores artesanais no estado do Rio Grande do Sul, Brasil. Revista Atlântica, 27(1): 17-29.

Gerhardinger, L. C., E. A. S. Godoy \& P. J. S. Jones. 2009. Local ecological knowledge and the management of marine protected areas in Brazil. Ocean \& Coastal Management, 52(3-4): 154165.

Gerhardinger, L. C., R. C. Marenzi, A. A. Bertoncini, R. P. Medeiros \& M. Hostim-Silva. 2006a. Local Ecological Knowledge on the Goliath Grouper Epinephelus itajara (Teleostei: Serranidae) in Southern Brazil. Neotropical Ichthyology, 4(4): 441-450.

Gerhardinger, L. C., A. A. Bertoncini \& M. Hostim-Silva. 2006b. Local ecological knowledge and Goliath grouper spawning aggregations in the South Atlantic Ocean: Goliath grouper spawning aggregations in Brazil. SPC Traditional Marine Resource Management and Knowledge Information Bulletin, 20: 33-34.

Grando, R. L. S. C. 2003. O conhecimento etnoecológico de pescadores da praia do Forte, litoral norte - BA: um saber ameaçado. Unpublished Monograph, Universidade Federal da Bahia, Salvador, $138 p$.

Hanazaki, N. 2003. Comunidades, conservação e manejo: o papel do conhecimento ecológico local. Biotemas, 16(1): 2347.

Huntington, H. P., R. S. Suydam \& D. H. Rosenberg. 2004. Traditional knowledge and satellite tracking as complementary approaches to ecological understanding. Environmental Conservation, 31(3): 177-180.

Instituto Brasileiro do Meio Ambiente e dos Recursos Naturais Renováveis - IBAMA. 2008. Estatística da pesca 2006 Brasil: grandes regiões e unidades da federação. Brasília, Ibama, $174 p$.

International Union for Conservation of Nature and Natural Resources - IUCN. 2008. IUCN Red List of Threatened Species. Available from: www.iucnredlist.org (March 09, 2009).

Johannes, R. \& E. Hviding. 2000. Traditional knowledge possessed by the fishers of Marovo Lagoon, Solomon Islands, concerning fish aggregating behavior. Traditional Marine Resource Management and Knowledge Information Bulletin, 12: 22-29.

Lessa, R. \& M. F. Nóbrega. 2000. Programa REVIZEE/SCORE-NE - Guia de identificação de peixes marinhos da região Nordeste. Recife, UFRPE-DIMAR, 128p.

Lowe Mc-Connell, R. H. 1999. Estudos Ecológicos em Comunidades de Peixes Tropicais. São Paulo, Editora da Universidade de São Paulo, 534p.

Marques, J. G. W. 1991. Aspectos ecológicos na etnoictiologia dos pescadores do Complexo Estuarino-lagunar Mundaú-Manguaba. Unpublished Ph.D. Thesis, Universidade Estadual de Campinas, Campinas, 291p.
Marques, J. G. W. 1995. Pescando pescadores: etnoecologia abrangente no baixo São Francisco. São Paulo, NUPAUB-USP, 304p.

Medeiros, P. R., R. G. Grempeli, S. T. Souza, M. I. Ilarri \& C. L. S. Sampaio. 2007. Effects of recreational activities on the fish assemblage structure in a northeastern Brazilian reef. PanAmerican Journal of Aquatic Sciences, 2(3): 288-300.

Menezes, N. A \& J. L. Figueiredo. 1980. Manual de peixes marinhos do sudeste do Brasil: IV. Teleostei. v. 3. São Paulo, Museu de Zoologia da USP, 96p.

Menezes, N. A \& J. L. Figueiredo. 1985. Manual de peixes marinhos do sudeste do Brasil: V. Teleostei. v. 4. São Paulo, Museu de Zoologia da USP, 105p.

Mourão, J. S. \& N. Nordi. 2002. Principais critérios utilizados por pescadores artesanais na taxonomia folk dos peixes do Estuário do Rio Mamanguape, Paraíba-Brasil. Interciência, 27(11): 607-612.

Mourão, J. S. \& N. Nordi. 2006. Pescadores, peixes, espaço e tempo: uma abordagem etnoecológica. Interciência, 31(5): 1-7.

Mussolini, G. 1980. Ensaios de antropologia indígena e caiçara. São Paulo, Paz e Terra, 289p.

Pacheco, R. S. 2006. Aspectos da ecologia de pescadores residentes na península de Maraú, Bahia: pesca, uso de recursos marinhos e dieta. Unpublished MSc. Dissertation, Universidade de Brasília, 68p.

Paz, V. \& A. Begossi. 1996. Ethnoichthyology of Gamboa fishermen of Sepetiba Bay, Brazil. Journal of Ethnobiology, 16(2): 157168.

Rezende, L. F. 2001. Estimativa dos padrões de circulação oceânica superficial baseado no lançamento de corpos de deriva e em derramamentos ocorridos no litoral Sul do estado da Bahia. Revista Tecnologia e Ambiente, 7(2): 73-89.

Rezende, S. M., B. P. Ferreira \& T. Fredou. 2003. A Pesca de Lutjanídeos no Nordeste do Brasil: histórico das pescarias, características das espécies e relevância para o manejo. Boletim Técnico Cientifico do CEPENE, 11(1): 56-63.

Silva, G. O. 1989. Tudo o que tem na terra tem no mar: a classificação dos seres vivos entre trabalhadores da pesca em Piratininga. Rio de Janeiro, FUNARTE/INF, 90p.

Silvano, R. A. M. 2001. Feeding habits and interspecific feeding associations of Caranx latus (Carangidae) in a subtropical reef. Environmental Biology of Fishes, 60(4): 465-470.

Silvano, R. A. M. 2004. Pesca artesanal e etnoictiologia. Pp. 187223. In: Begossi, A. (Org.). Ecologia de Pescadores da Mata Atlântica e da Amazônia. São Paulo, Fapesp/Hucitec, 332p.

Silvano, R. A. M. \& A. Begossi. 2002. Ethnoichthyology and fish conservation in the Piracicaba River (Brazil). Journal of ethnobiology, 22(2): 285-306.

Silvano, R. A. M. \& E. J. V. Jorgensen. 2008. Beyond fishermen’s tales: contributions of fishers' local ecological knowledge to fish ecology and fisheries management. Environment, Development and Sustainability, 10(5): 657-675.

Silvano, R. A. M., P. F. L. Maccord, R. V. Lima \& A. Begossi. 2006. When does this fish spawn? Fishermen's local knowledge of migration and reproduction of Brazilian coastal fish. Environmental Biology of Fish, 76(2-4): 371-381.

Souto, F. J. B. 2007. Uma abordagem etnoecológica da pesca do caranguejo, Ucides cordatus, Linnaeus, 1763 (Decapoda: Brachyura), no manguezal do Distrito de Acupe (Santo AmaroBA). Biotemas, 20(1): 69-80.

Thé, A. P. G. \& N. Nordi. 2006. Common Property Resource System in a Fishery of the San Francisco River, Minas Gerais, Brazil. Human Ecology Review, 13(1): 1-10. 
Thompson, R. \& J. L. Mumot. 1978. Aspects of the biology and ecology of Caribbean reef fishes: Serranidae (hinds and groupers). Journal of Fish Biology, 12: 115-146.

Vasconcellos, M. C. \& M. A. Gasalla. 2001. Fisheries catches and the carrying capacity of marine ecosystems of Southern Brazil. Fisheries Research, 51(3): 279-295.

Accepted July 12, 2009

Published September 30, 2009 